\title{
Synthesis of aryl cyclopropyl sulfides through copper-promoted S-cyclopropylation of thiophenols using cyclopropylboronic acid
}

\author{
Emeline Benoit, Ahmed Fnaiche and Alexandre Gagnon*
}

\author{
Letter \\ Address: \\ Département de chimie, Université du Québec à Montréal, C.P. 8888 , \\ Succursale Centre-Ville, Montréal, Québec, H3C 3P8, Canada \\ Email: \\ Alexandre Gagnon* - gagnon.alexandre@uqam.ca \\ * Corresponding author \\ Keywords: \\ aryl cyclopropyl sulfides; copper(II) acetate; copper catalysis; \\ cyclopropylboronic acid; thiophenols
}

\author{
Beilstein J. Org. Chem. 2019, 15, 1162-1171. \\ doi:10.3762/bjoc. 15.113
}

Received: 10 April 2019

Accepted: 22 May 2019

Published: 27 May 2019

This article is part of the thematic issue "Copper-catalyzed reactions for organic synthesis".

Guest Editor: G. Evano

(C) 2019 Benoit et al.; licensee Beilstein-Institut.

License and terms: see end of document.

\begin{abstract}
The copper-promoted S-cyclopropylation of thiophenols using cyclopropylboronic acid is reported. The procedure operates under simple conditions to afford the corresponding aryl cyclopropyl sulfides in moderate to excellent yields. The reaction tolerates substitution in ortho-, meta- and para-substitution as well as electron-donating and electron-withdrawing groups. The S-cyclopropylation of a thiophenol was also accomplished using potassium cyclopropyl trifluoroborate.
\end{abstract}

\section{Introduction}

Aryl cyclopropyl sulfides are present in many biologically active compounds, mainly in their oxidized forms. For example, aryl cyclopropyl sulfones have been used in the preparation of glucokinase (GK) activators for the treatment of type 2 diabetes [1-5] while aryl cyclopropyl sulfoximines have been utilized for the synthesis of modulators of glucokinase regulatory protein (GKRP) [6-8]. Roniciclib, also named BAY 1000394, is a pan-cyclin-dependant kinase (CDK) inhibitor that contains an aryl cyclopropyl sulfoximine and that was developed to treat patients with untreated small cell lung cancer $[6,9]$.
Aryl cyclopropyl sulfides $\mathbf{1}$ are also remarkable synthons in organic synthesis (Scheme 1). For instance, the proton alpha to the sulfur can be removed by a strong base such as butyllithium, resulting in the cyclopropyllithium species $\mathbf{2}$. This carbanion can then react with alkyl halides to provide the corresponding alkylated species 3 which can then be opened up by treatment with mercuric chloride to give the corresponding $\beta$-thioaryl ketone 4 [10]. Reacting 2 with epoxides results in the formation of the 1-( $\beta$-hydroxy)cyclopropyl aryl sulfides 5 [10] while reaction with formaldehydes [11] or aldehydes [12] affords 


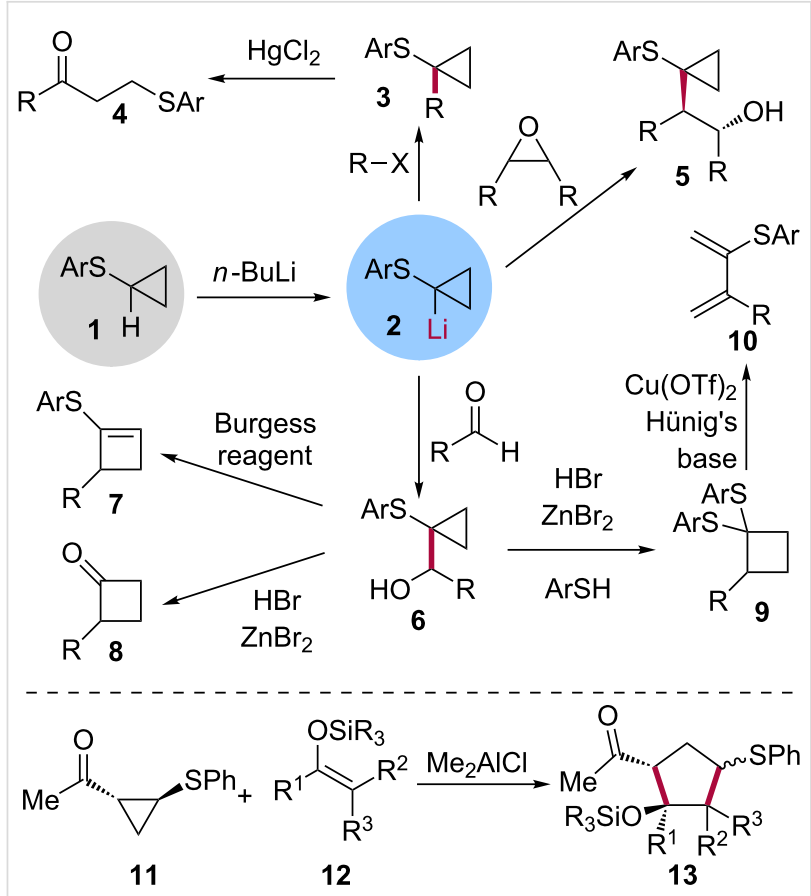

Scheme 1: Synthetic uses of aryl cyclopropyl sulfides 1.

1-(arylthio)cyclopropylcarbinyl alcohols $\mathbf{6}$. Treating 6 with Burgess reagent or with hydrobromic acid and zinc bromide leads to 1-arylthiocyclobutenes 7 [13] and 2-alkyl-substituted cyclobutanones 8 [11,12], respectively. Treatment of $\mathbf{6}$ with hydrobromic acid and zinc bromide in the presence of a thiophenol provides the 1,1-di(arylthio)cyclobutane 9 which, upon reaction with copper(II) triflate and Hünig's base, rearranges to give the corresponding 2-(arylthio)-3-alkyl-1,3-butadiene $\mathbf{1 0}$ [12]. Reacting methyl 2-phenylthiocyclopropyl ketone 11 with silyl enol ethers $\mathbf{1 2}$ in the presence of dimethylaluminium chloride leads to the functionalized cyclopentanes $\mathbf{1 3}$ via a highly diastereoselective $[3+2]$ cycloaddition reaction $[14,15]$. The ring expansion sequence $\mathbf{1} \rightarrow \mathbf{2} \rightarrow \mathbf{6} \rightarrow \mathbf{8}$ has been used as a key step in the synthesis of ( \pm )-fragranol [16], ( \pm )-grandisol [16], ( \pm )- $\alpha$-cuparenone [17] and ( \pm )-herbertene [17].

Aryl cycloropyl sulfides $\mathbf{1}$ are most frequently prepared by cyclopropylation of thiophenols 14 through $\mathrm{S}_{\mathrm{N}} 2$ reaction with cyclopropyl bromide $(\mathbf{1 5}$, Scheme $2 \mathrm{a})[2,4]$ or by $\mathrm{S}_{\mathrm{N}} \mathrm{Ar}$ reaction between aryl fluorides $\mathbf{1 6}$ and cyclopropanethiol (17, (Scheme 2b) [6]. Although simple and attractive, these approaches usually require harsh conditions such as the presence of a strong base and high temperatures [18]. In addition, an electron-withdrawing group (EWG) must be present on the aryl fluoride $\mathbf{1 6}$ for the $\mathrm{S}_{\mathrm{N}} \mathrm{Ar}$ reaction to proceed. Aryl cyclopropyl sulfides can also be accessed by the addition of thiophenols 14 to cyclopropenes 18 (Scheme 2c) [19,20] or to exo-methylenecyclopropanes 20 (Scheme 2d) [21,22]. While these methods give access to highly substituted products, the requirement for a strong base could jeopardize their application in the context of synthesis of complex molecules. Furthermore, an electron-withdrawing group must be present on $\mathbf{1 8}$ to enable the Michael addition with thiol 14. Treatment of 1,3-bis(phenylthio)propanes 22 with butyllithium is another way of accessing substituted aryl cyclopropyl sulfides 23 (Scheme 2e) [23]. However, in addition to requiring a very strong base, the generation of regio- and stereoisomers from a complex starting material reduces the attractiveness of this method, particularly with respect to medicinal chemistry where expedient methods from easily accessible substrates are needed.

Organobismuth compounds are organometallic reagents that possess a $\mathrm{C}-\mathrm{Bi}$ bond and which can be synthesized from inexpensive and low-toxic bismuth salts $[24,25]$. Due to the borderline behavior of bismuth as a metal and a ligand, organobismuth species have been used as reagents and catalysts in a wide range of reactions. We reported a portfolio of methods for the construction of $\mathrm{C}-\mathrm{C}$ [26-29], $\mathrm{C}-\mathrm{N}$ [30] and $\mathrm{C}-\mathrm{O}$ bonds [31-33] using triaryl- and trialkylbismuthines [34]. We also disclosed for the first time in 2007 the synthesis of tricyclopropylbismuth (24) and its use in N-cyclopropylation [35], palladium-catalyzed cross coupling [36] and carbonylative cross-coupling reactions [37]. Recently, we demonstrated that tricyclopropylbismuth (24) can be used to S-cyclopropylate thiophenols 14, giving access to aryl cyclopropyl sulfides 1 (Scheme 2f) [38]. While this constituted the first example on the use of an organobismuth reagent in the construction of $\mathrm{C}\left(\mathrm{sp}^{3}\right)-\mathrm{S}$ bonds, synthetically, the method showed limitations such as the need for a high excess of tricyclopropylbismuth (24) which transfers only one cyclopropyl unit out of three to deliver the desired products in moderate yields.

Cyclopropylboronic acid has been elegantly used by Neuville and Zhu [39,40], Tsuritani [41], Taillefer [42], Hayashi [43] and Reddy [44] as a cyclopropylating reagent in N-cyclopropylation reactions, a transformation which is similar to the Chan [45], Evans [46], Lam [47] arylation reaction of $\mathrm{N}-\mathrm{H}$ and $\mathrm{O}-\mathrm{H}$ containing substrates. These seminal reports greatly contributed to the synthesis of cyclopropylated compounds in addition to expanding the scope of copper-catalyzed reactions in organic synthesis [48-51]. Our interest in cyclopropylation reactions led us to explore the use of cyclopropylboronic acid in the O-cyclopropylation of phenols. Unfortunately, efficient conditions could not be identified to perform this seemingly simple extension of the N-cyclopropylation reaction. Very recently, Engle and McAlpine disclosed a solution to this problem by developing a highly efficient protocol for the direct O-cyclopropylation of phenols using potassium cyclopropyl trifluoroborate [52]. Surprisingly, and to the best of our knowledge, cyclo- 
a) cyclopropylation of thiophenols via $\mathrm{S}_{\mathrm{N}} 2$

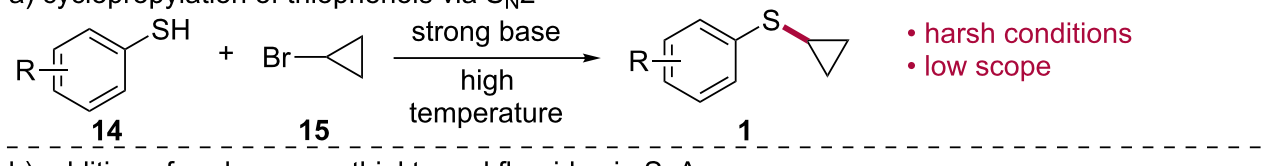

b) addition of cyclopropanethiol to aryl fluoride via $\mathrm{S}_{\mathrm{N}} \mathrm{Ar}$

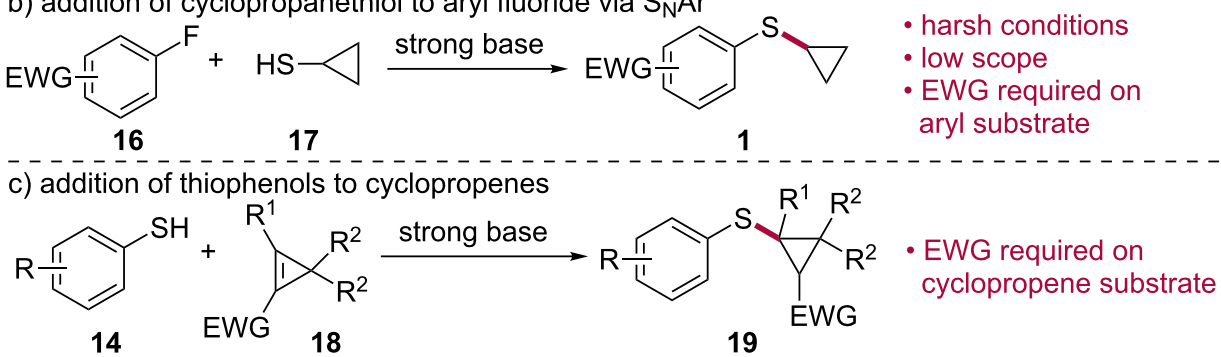

$\mathrm{R}_{1}=\mathrm{H}$ or TMS, $\mathrm{R}_{2}=\mathrm{H}$ or $\mathrm{Me}$

d) addition of thiophenols to exo-methylenecyclopropanes
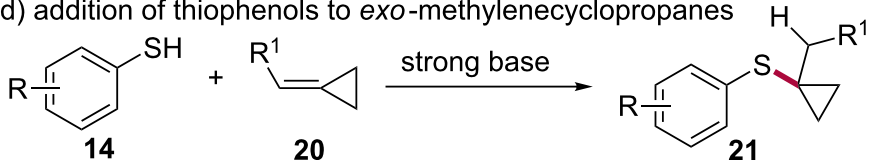

- generation of regioisomers

e) cyclization of 1,3-bis(phenylthio)propanes
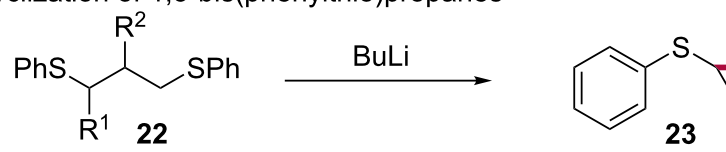

$\mathrm{R}^{1}$

strong base required $23 R^{2}$

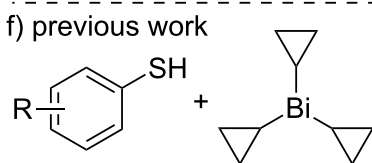

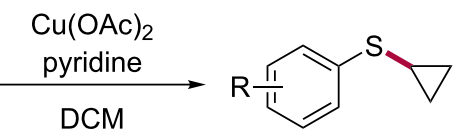

1

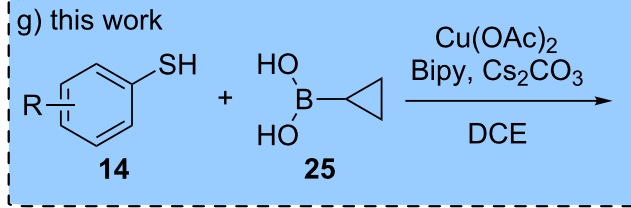

- non commercial

cyclopropylating reagent

- two cPr groups wasted propylboronic acid or its various ester and potassium trifluoroborate derivatives have never been used in S-cyclopropylation reactions. In light of the relevance of aryl cyclopropyl sulfides in medicinal and synthetic organic chemistry, we initiated a program to explore the use of cyclopropylboronic acid (25) as an S-cyclopropylating agent of thiophenols (Scheme 2g). The publication of copper-catalyzed methods by Feng and $\mathrm{Xu}$ to S-arylate thiophenols [53] and by Guy to S-arylate alkyl thiols [54] gave us confidence to proceed ahead with our endeavour for which we herein report our results.

\section{Results and Discussion}

We began by testing the feasibility of S-cyclopropylating 4-tertbutylbenzenethiol (14a) with cyclopropylboronic acid (25) using reaction conditions developed by Neuville and Zhu for the N-cyclopropylation of anilines and amines [39]. Treating thiophenol 14a with 2.0 equivalents of cyclopropylboronic acid
(25), 1.0 equivalent of copper(II) acetate, 1.0 equivalent of bipyridine, and 2.0 equivalents of sodium carbonate in dichloroethane at $70{ }^{\circ} \mathrm{C}$ for 16 hours provided the desired $S$-cyclopropylated compound 1a in $86 \%$ yield accompanied by only $4 \%$ of the diaryl disulfide side-product 26a (Table 1, entry 1, "standard conditions"). Reducing the catalyst loading by a factor of two under oxygen atmosphere led to a dramatic reduction in the yield of the reaction (Table 1, entry 2). Performing the reaction under oxygen with a stoichiometric amount of copper(II) acetate also proved unsuccessful and afforded mainly the disulfide product, suggesting a deleterious effect of oxygen (Table 1, entry 3 ). Yet, to our surprise, performing the reaction under argon also negatively impacted the yield of the reaction (Table 1, entry 4), showing that air is the ideal (and also most convenient) atmosphere for this reaction. Changing the solvent for toluene, dichloromethane, dimethylformamide or $\mathrm{DMF} / \mathrm{H}_{2} \mathrm{O}$ (4:1) led to lower yields of the desired aryl cyclopropyl sulfide 
Table 1: Optimization of the reaction conditions for the copper-promoted S-cyclopropylation of thiophenol 14a with boron-based cyclopropylating reagents.

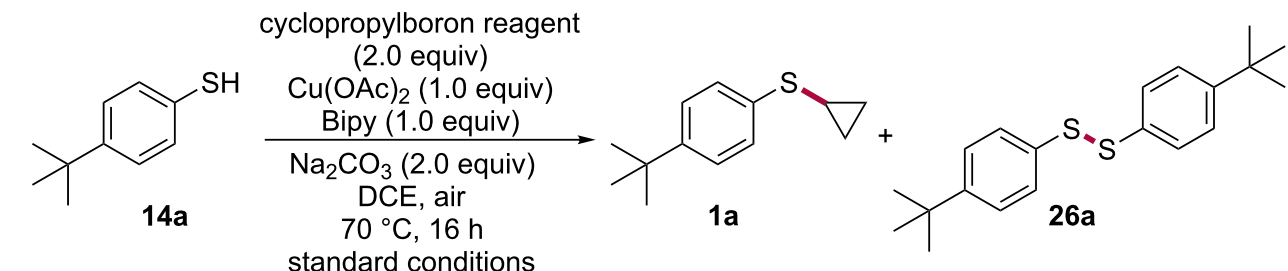
standard conditions

cyclopropylboron reagent
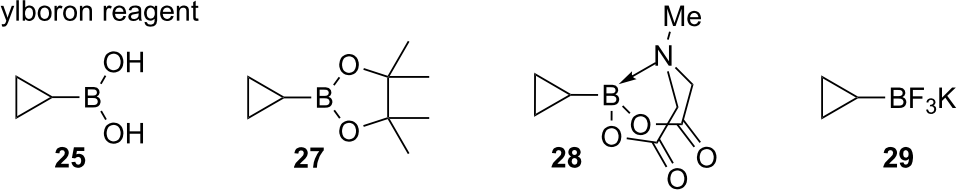

\begin{tabular}{|c|c|c|c|}
\hline Entry & Change from "standard conditions"a & Yield 1a (\%) & Yield 26a $(\%)^{b}$ \\
\hline 1 & no change ${ }^{a}$ & 86 & 4 \\
\hline 2 & 0.5 equiv of $\mathrm{Cu}(\mathrm{OAc})_{2}$ instead of 1.0 equiv under $\mathrm{O}_{2}$ instead of air & 10 & 0 \\
\hline 3 & $\mathrm{O}_{2}$ instead of air & 19 & 62 \\
\hline 4 & argon instead of air & 45 & 4 \\
\hline 5 & toluene, DCM, DMF or DMF/ $\mathrm{H}_{2} \mathrm{O}(4: 1)$ instead of DCE & $<40$ & 0 \\
\hline 6 & $50^{\circ} \mathrm{C}$ instead of $70^{\circ} \mathrm{C}$ & 7 & 20 \\
\hline 7 & 1,10-phenanthroline instead of bipy & 81 & 0 \\
\hline 8 & 1.5 equiv of $\mathrm{cPrB}(\mathrm{OH})_{2}(25)$ instead of 2.0 and 1.0 equiv of $\mathrm{Na}_{2} \mathrm{CO}_{3}$ & 85 & 14 \\
\hline 9 & $\begin{array}{l}1.5 \text { equiv of } \mathrm{cPrB}(\mathrm{OH})_{2}(25) \text { instead of } 2.0 \text { and } 1.0 \text { equiv of } \mathrm{Cs}_{2} \mathrm{CO}_{3} \text { instead of } \\
2.0 \text { equiv of } \mathrm{Na}_{2} \mathrm{CO}_{3}\end{array}$ & 92 & 6 \\
\hline 10 & $\begin{array}{l}1.5 \text { equiv of } \mathrm{cPrB}(\mathrm{OH})_{2}(25) \text { instead of } 2.0,1.0 \text { equiv of } \mathrm{Cs}_{2} \mathrm{CO}_{3} \text { instead of } 2.0 \text { equiv of } \\
\mathrm{Na}_{2} \mathrm{CO}_{3} \text { and } 6 \mathrm{~h} \text { instead of } 16 \mathrm{~h}\end{array}$ & 85 & 14 \\
\hline 11 & 27 instead of $\mathrm{cPrB}(\mathrm{OH})_{2}(\mathbf{2 5})$ & 0 & $85^{c}$ \\
\hline 12 & 28 instead of $\mathrm{cPrB}(\mathrm{OH})_{2}(\mathbf{2 5})$ & 0 & $96^{c}$ \\
\hline 13 & 29 instead of $\mathrm{cPrB}(\mathrm{OH})_{2}(25)$ & 23 & 30 \\
\hline
\end{tabular}

aStandard conditions: 4-tert-butylbenzenethiol (14a, 1.0 equiv), cyclopropylboronic acid (25, 2.0 equiv), Cu(OAc) 2 (1.0 equiv), bipyridine (1.0 equiv),

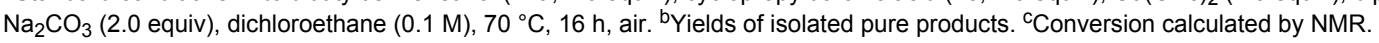

1a (Table 1, entry 5) while decreasing the temperature to $50{ }^{\circ} \mathrm{C}$ almost completely shut down the reaction (Table 1 , entry 6). 1,10-Phenanthroline was found to be the only viable alternative to bipyridine (Table 1, entry 7), with other ligands commonly used in copper-catalyzed reactions such as proline and 2,2,6,6tetramethyl-3,5-heptanedione giving yields under $15 \%$. Reducing the number of equivalents of boronic acid 25 and sodium carbonate was found to be well tolerated, giving a comparable yield as the "standard conditions" (Table 1, entry 8). While changing the inorganic base to potassium phosphate tribasic or potassium carbonate gave yields below $75 \%$, we found that cesium carbonate provided a net increase in the yield of the reaction (Table 1, entry 9). Attempts at reducing the reaction time led to a minor erosion in the yield of the reaction (Table 1, entry 10). Replacing cyclopropylboronic acid (25) with cyclopropylboronic acid pinacol ester (27) or cyclopropylboronic acid MIDA ester $\mathbf{2 8}$ afforded $85 \%$ and $96 \%$ of the corresponding diaryl disulfide 26a, respectively, with no obsevable traces of the desired S-cyclopropylated product 1a (Table 1, entries 11 and 12). Interestingly, however, potassium cyclopropyl trifluoroborate (29) provided the desired aryl cyclopropyl sulfide 1a in $23 \%$ yield, albeit with $30 \%$ of the diaryl disulfide sideproduct 26a (Table 1, entry 13). Although encouraging, it was clear that the S-cyclopropylation with $\mathrm{CPrBF}_{3} \mathrm{~K}$ (29) would necessitate extensive optimization and therefore, we decided to pursue our work with $\mathrm{cPrB}(\mathrm{OH})_{2}$ (25).

With our optimized reactions conditions in hand (i.e., Table 1, entry 9), we embarked on exploring the scope of the copperpromoted S-cyclopropylation of thiophenols using cyclopropylboronic acid (25, Scheme 3$)$. Our studies showed that the reaction can be performed on unsubstituted benzenethiol as well as on para- and meta-methylbenzenethiols, affording the corresponding products $\mathbf{1 b}-\mathbf{d}$ in 84 to $99 \%$ yield. Substitution of the aryl ring at the ortho-position resulted in a considerable drop in the efficiency of the process, as indicated by compound $\mathbf{1 e}$ 


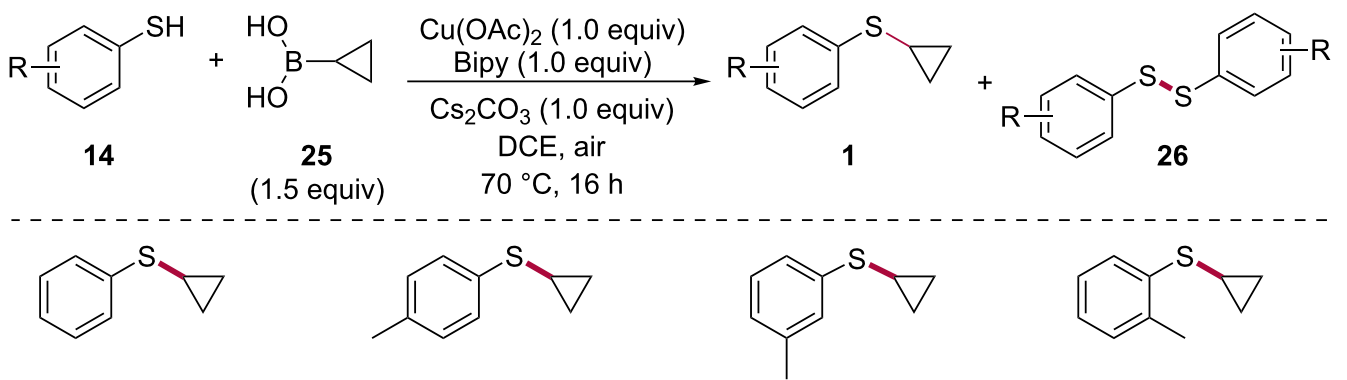

1b: $99 \%(0 \%$ 1c: $94 \%(0 \%)$ 1d: $84 \%(14 \%)$ 1e: $57 \%(16 \%)$<smiles>Cc1cc(C)cc(SC2CC2)c1</smiles><smiles>Cc1ccc(SC2CC2)c(C)c1</smiles><smiles>Fc1ccc(SC2CC2)cc1</smiles><smiles>Brc1ccc(SC2CC2)cc1</smiles>

1f: $76 \%(24 \%)$ 1g: $31 \%(33 \%)$ 1h: $83 \%(0 \%)$ 1i: $95 \%(2 \%)$<smiles>Clc1ccc(SC2CC2)cc1</smiles>

1j: $72 \%(22 \%)$<smiles>COc1ccc(SC2CC2)cc1</smiles>

$1 \mathrm{~m}: 80 \%(2 \%)$<smiles>FC(F)(F)c1ccc(SC2CC2)cc1</smiles>

1k: $72 \%(0 \%)$<smiles>Brc1cccc(SC2CC2)c1</smiles><smiles>O=[N+]([O-])c1ccc(SC2CC2)cc1</smiles>

1I: $78 \%(0 \%)$<smiles>COC(=O)c1ccccc1SC1CC1</smiles>

10: $44 \%(36 \%)$

Scheme 3: Substrate scope in the copper-promoted S-cyclopropylation of thiophenols 14 using cyclopropylboronic acid (25). Numbers in parentheses indicate the yield of isolated pure diaryl disulfide side-products 26.

which was obtained in a moderate $57 \%$ yield. In line with those results, cyclopropyl(3,5-dimethylphenyl)sulfane (1f) was obtained in $76 \%$ yield while the 2,4 -isomer $1 \mathrm{~g}$ was produced in a low $31 \%$ yield. Electron-withdrawing groups such as a fluorine, bromine, chlorine, trifluoromethyl and a nitro group as well as electron-donating groups such as a methoxy group at the paraposition were found to be well tolerated, as indicated by aryl cyclopropyl sulfides $\mathbf{1 h}-\mathbf{m}$ which were obtained in yields ranging from 72 to $95 \%$. Moving the bromine from the para- to the meta-position resulted in a substantial reduction in the yield of the reaction, as shown by compound $\mathbf{1 n}$. Compound $\mathbf{1 0}$ possessing a methyl ester at the ortho-position was prepared in $44 \%$, a yield which is consistent with the one obtained for the ortho-methyl product 1e. Compound 10 indicates some level of tolerance towards functional groups that can be used à posteriori to modify the product. Diaryl disulfides $\mathbf{2 6}$ were isolated in yields ranging from 2 to $36 \%$, depending on the thiophenol. Attempts at S-cyclopropylating benzyl mercaptan, an alkylthiol, failed to deliver the desired product.

Engle and McAlpine recently reported a very efficient, simple and general protocol for the O-cyclopropylation of phenols using potassium cyclopropyl trifluoroborate (29) that leads to the corresponding aryl cyclopropyl ethers in good to excellent yields [52]. We wanted to study the transposibility of these conditions to the S-cyclopropylation of thiophenols. In the event, treating 4-tert-butylbenzenethiol (14a) with 3.0 equivalents of potassium cyclopropyl trifluoroborate (29) in the presence of 0.1 equivalents of copper(II) acetate, 0.1 equivalents of 1,10-phenanthroline, 2.0 equivalents of potassium carbonate under oxygen atmosphere at $70{ }^{\circ} \mathrm{C}$ for 20 hours in a $3: 1 \mathrm{mix}-$ ture of toluene and water afforded the aryl cyclopropyl sulfide 1a in $38 \%$ along with $8 \%$ of the corresponding side-product $26 \mathbf{a}$ and $24 \%$ of recovered starting material $14 a$ (Scheme 4 ). These results are encouraging and demonstrate that the Engle/ McAlpine conditions are applicable, to some extent, to the S-cyclopropylation of thiophenols. It is reasonable to believe that thorough optimization of the reaction conditions should result in a more efficient process. Efforts towards this goal are in progress in our laboratory and results will be reported in due course.

\section{Conclusion}

In conclusion, we developed a simple protocol for the S-cyclopropylation of thiophenols using cyclopropylboronic acid. The reaction is promoted by copper(II) acetate and tolerates electron-withdrawing and electron-donating groups at the ortho-, meta-, and para-positions of the aryl ring to afford the corre- 


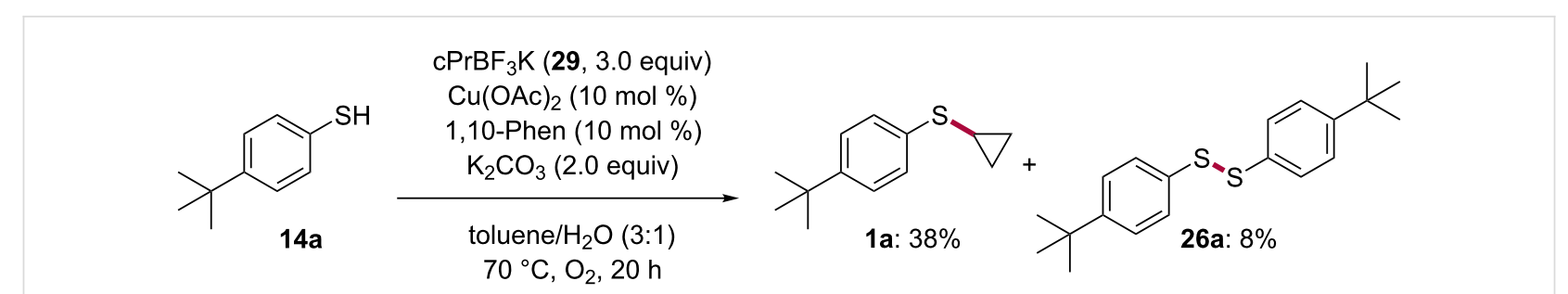

Scheme 4: Copper-catalyzed S-cyclopropylation of 4-tert-butylbenzenethiol (14a) using potassium cyclopropyl trifluoborate (29).

sponding aryl cyclopropyl sulfides in moderate to excellent yields. This protocol provides an efficient alternative to our previously reported method for the S-cyclopropylation of thiophenols using tricyclopropylbismuth.

\section{Experimental}

\section{General information}

Unless otherwise indicated, all reactions were run under argon in flame-dried glassware. Commercial reagents were used without further purification. $\mathrm{Cu}(\mathrm{OAc})_{2}(97 \%)$ was purchased from Strem Chemicals. Anhydrous solvents were obtained using an encapsulated solvent purification system and were further dried over $4 \AA$ molecular sieves. The evolution of reactions was monitored by analytical thin-layer chromatography using silica gel 60 F254 precoated plates. Flash chromatography was performed employing 230-400 mesh silica using the indicated solvent system according to standard techniques. Proton nuclear magnetic resonance spectra were recorded on a 300 or $600 \mathrm{MHz}$ spectrometer. Chemical shifts for ${ }^{1} \mathrm{H}$ NMR spectra are recorded in parts per million from tetramethylsilane with the solvent resonance as the internal standard (chloroform, $\delta 7.26 \mathrm{ppm}$ ). Data is reported as follows: chemical shift $\delta$, multiplicity ( $\mathrm{s}=$ singlet, $\mathrm{d}=$ doublet, $\mathrm{t}=$ triplet, $\mathrm{dd}=$ doublet of doublet, $\mathrm{ddd}=$ doublet of doublet of doublet, $\mathrm{td}=$ triplet of doublet, $\mathrm{m}=$ multiplet), coupling constant $J$ in $\mathrm{Hz}$ and integration. Melting points are uncorrected.

\section{General procedure for the synthesis of aryl cyclopropyl sulfides}

A sealed tube equipped with a magnetic stirring bar was charged under ambiant air with cyclopropylboronic acid (25, $0.6 \mathrm{mmol}, 1.5$ equiv), cesium carbonate ( $0.4 \mathrm{mmol}, 1.0$ equiv), $\mathrm{Cu}(\mathrm{OAc})_{2}$ (0.4 mmol, 1.0 equiv), 2,2'-bipyridine ( $0.4 \mathrm{mmol}$, 1.0 equiv) and thiophenol 14 ( $0.4 \mathrm{mmol}, 1.0$ equiv). Dichloroethane $(0.1 \mathrm{M})$ was added, the tube was sealed and heated at $70{ }^{\circ} \mathrm{C}$ for 16 hours. The reaction mixture was cooled to room temperature and aqueous $\mathrm{NH}_{4} \mathrm{OH} 25 \%(5 \mathrm{~mL})$ was added. The reaction mixture was stirred for a few minutes, transferred in a separatory funnel and extracted with DCM $(3 \times 5 \mathrm{~mL})$. The combined organic layers were washed with brine $(2 \times 10 \mathrm{~mL})$ dried over anhydrous $\mathrm{Na}_{2} \mathrm{SO}_{4}$ and concentrated under reduced pressure. The residue was purified by flash column chromatography using the indicated solvent system to afford the corresponding aryl cyclopropyl sulfide $\mathbf{1}$ and diaryl disulfide $\mathbf{2 6}$ as a side-product.

(4-(tert-Butyl)phenyl)(cyclopropyl)sulfane (1a) and 1,2bis(4-(tert-butyl)phenyl)disulfane (26a). The general procedure was followed on $0.425 \mathrm{mmol}$ scale starting from 4 -(tertbutyl)benzenethiol (14a). The residue was purified on silica gel (100\% Hex) to afford 1a (80.4 mg, 92\%) and 26a (4.2 mg, 6\%) as a colorless oil and a white solid, respectively. 1a: Spectral data was identical to literature compound [38]. ${ }^{1} \mathrm{H}$ NMR $\left(300 \mathrm{MHz}, \mathrm{CDCl}_{3}\right) \delta 7.33(\mathrm{~s}, 4 \mathrm{H}), 2.23-2.16(\mathrm{~m}, 1 \mathrm{H}), 1.33(\mathrm{~s}$, 9H), 1.08-1.02 (m, 2H), 0.73-0.68 (m, 2H). 26a: mp 65.0-68.5 ${ }^{\circ} \mathrm{C}$. Spectral data was identical to literature compound [55]. ${ }^{1} \mathrm{H}$ NMR $\left(300 \mathrm{MHz}, \mathrm{CDCl}_{3}\right) \delta 7.44(\mathrm{~d}, J=8.7 \mathrm{~Hz}$, $2 \mathrm{H}), 7.33(\mathrm{~d}, J=8.4 \mathrm{~Hz}, 2 \mathrm{H}), 1.30(\mathrm{~s}, 9 \mathrm{H})$.

Cyclopropyl(phenyl)sulfane (1b). The general procedure was followed on $0.400 \mathrm{mmol}$ scale starting from benzenethiol (14b). The residue was purified on silica gel $(100 \% \mathrm{Hex})$ to afford $\mathbf{1 b}$ (59.2 mg, 99\%) as a slightly yellow oil: Spectral data was identical to literature compound [38]. ${ }^{1} \mathrm{H}$ NMR $\left(300 \mathrm{MHz}, \mathrm{CDCl}_{3}\right)$

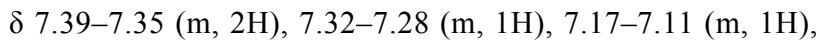
$2.23-2.15(\mathrm{tt}, J=8.4,1.2 \mathrm{~Hz}, 1 \mathrm{H}), 1.10-1.04(\mathrm{~m}, 2 \mathrm{H})$, $0.72-0.62(\mathrm{~m}, 2 \mathrm{H})$.

Cyclopropyl(p-tolyl)sulfane (1c). The general procedure was followed on $0.400 \mathrm{mmol}$ scale starting from 4-methylbenzenethiol (14c). The residue was purified on silica gel $(100 \%$ Hex) to afford 1c $(61.8 \mathrm{mg}, 94 \%)$ as a colorless oil: Spectral data was identical to literature compound [38]. ${ }^{1} \mathrm{H}$ NMR $\left(300 \mathrm{MHz}, \mathrm{CDCl}_{3}\right) \delta 7.29(\mathrm{~d}, J=3.9 \mathrm{~Hz}, 2 \mathrm{H}), 7.12(\mathrm{~d}$, $J=4.2 \mathrm{~Hz}, 2 \mathrm{H}), 2.33(\mathrm{~s}, 3 \mathrm{H}), 2.22-2.18(\mathrm{~m}, 1 \mathrm{H}), 1.06-1.03(\mathrm{~m}$, $2 \mathrm{H}), 0.71-0.68(\mathrm{~m}, 2 \mathrm{H})$.

Cyclopropyl(m-tolyl)sulfane (1d) and 1,2-di(m-tolyl)disulfane (26d). The general procedure was followed on $0.400 \mathrm{mmol}$ scale starting from 3-methylbenzenethiol (14d). The residue was purified on silica gel $(100 \% \mathrm{Hex})$ to afford $1 \mathrm{~d}(55.2 \mathrm{mg}$, $84 \%$ ) and $\mathbf{2 6 d}(6.9 \mathrm{mg}, 14 \%)$ as a colorless and a yellow oil, re- 
spectively. 1d: Spectral data was identical to literature compound [38]. ${ }^{1} \mathrm{H}$ NMR $\left(300 \mathrm{MHz}, \mathrm{CDCl}_{3}\right) \delta 7.19-7.18(\mathrm{~m}, 3 \mathrm{H})$, 6.97-6.94 (m, 1H), $2.34(\mathrm{~s}, 3 \mathrm{H}), 2.23-2.15(\mathrm{~m}, 1 \mathrm{H}), 1.09-1.03$ $(\mathrm{m}, 2 \mathrm{H}), 0.72-0.67(\mathrm{~m}, 2 \mathrm{H})$. 26d: Spectral data was identical to literature compound [56]. ${ }^{1} \mathrm{H}$ NMR $\left(300 \mathrm{MHz}, \mathrm{CDCl}_{3}\right) \delta 7.32$ (s, 2H), 7.30 (d, $J=3.9 \mathrm{~Hz}, 2 \mathrm{H}), 7.19$ (t, $J=8.0 \mathrm{~Hz}, 2 \mathrm{H}), 7.03$ (d, $J=7.5 \mathrm{~Hz}, 2 \mathrm{H}), 2.32(\mathrm{~s}, 6 \mathrm{H})$.

Cyclopropyl(o-tolyl)sulfane (1e) and 1,2-di(o-tolyl)disulfane (26e). The general procedure was followed on $0.400 \mathrm{mmol}$ scale starting from 2-methylbenzenethiol (14e). The residue was purified on silica gel (100\% Hex) to afford 1e (37.5 mg, 57\%) and $26 \mathrm{e}(7.9 \mathrm{mg}, 16 \%)$ as a slightly yellow and a yellow oil, respectively. 1e: Spectral data was identical to literature compound [38]. ${ }^{1} \mathrm{H}$ NMR $\left(300 \mathrm{MHz}, \mathrm{CDCl}_{3}\right) \delta 7.53(\mathrm{~d}, J=7.5 \mathrm{~Hz}$, $1 \mathrm{H}), 7.20(\mathrm{td}, J=7.5,1.8 \mathrm{~Hz}, 1 \mathrm{H}), 7.15-7.03(\mathrm{~m}, 2 \mathrm{H}), 2.27(\mathrm{~s}$, $3 \mathrm{H}), 2.17-2.09(\mathrm{~m}, 1 \mathrm{H}), 1.13-1.07(\mathrm{~m}, 2 \mathrm{H}), 0.73-0.67(\mathrm{~m}, 2 \mathrm{H})$. 26e: Spectral data was identical to literature compound [57]. ${ }^{1} \mathrm{H}$ NMR (300 MHz, $\left.\mathrm{CDCl}_{3}\right) \delta$ 7.52-7.49 (m, 2H), 7.17-7.09 $(\mathrm{m}, 6 \mathrm{H}), 2.43(\mathrm{~s}, 6 \mathrm{H})$.

Cyclopropyl(3,5-dimethylphenyl)sulfane (1f) and 1,2bis(3,5-dimethylphenyl)disulfane (26f). The general procedure was followed on $0.400 \mathrm{mmol}$ scale starting from 3,5dimethylbenzenethiol (14f). The residue was purified on silica gel (100\% Hex) to afford $\mathbf{1 f}(54.2 \mathrm{mg}, 76 \%)$ and $\mathbf{2 6 f}$ (13.2 $\mathrm{mg}$, $24 \%$ ) as a colorless and a yellow oil, respectively. 1f: Spectral data was identical to literature compound [38]. ${ }^{1} \mathrm{H}$ NMR $\left(300 \mathrm{MHz}, \mathrm{CDCl}_{3}\right) \delta 6.99(\mathrm{~s}, 2 \mathrm{H}), 6.78(\mathrm{~s}, 1 \mathrm{H}), 2.30(\mathrm{~s}, 6 \mathrm{H})$, 2.22-2.14 (m, 1H), 1.08-1.02 (m, 2H), 0.71-0.66 (m, 2H). 26f: Spectral data was identical to literature compound [58]. ${ }^{1} \mathrm{H}$ NMR (300 MHz, $\left.\mathrm{CDCl}_{3}\right) \delta 7.12(\mathrm{~s}, 4 \mathrm{H}), 6.85$ (s, 2H), 2.28 (s, 12H).

Cyclopropyl(2,4-dimethylphenyl)sulfane (1g) and 1,2bis(2,4-dimethylphenyl)disulfane (26g). The general procedure was followed on $0.371 \mathrm{mmol}$ scale starting from 2,4dimethylbenzenethiol $(\mathbf{1 4 g})$. The residue was purified on silica gel (100\% Hex) to afford $\mathbf{1 g}(20.5 \mathrm{mg}, 31 \%)$ and $\mathbf{2 6 g}$ (17.3 $\mathrm{mg}$, $33 \%)$ as colorless oils. 1g: Spectral data was identical to literature compound [38]. ${ }^{1} \mathrm{H}$ NMR $\left(300 \mathrm{MHz}, \mathrm{CDCl}_{3}\right) \delta 7.41$ (d, $J=3.9 \mathrm{~Hz}, 1 \mathrm{H}), 7.00(\mathrm{~d}, J=3.9 \mathrm{~Hz}, 1 \mathrm{H}), 6.96(\mathrm{~s}, 1 \mathrm{H}), 2.29$ (s, $3 \mathrm{H}), 2.25(\mathrm{~s}, 3 \mathrm{H}), 2.14-2.10(\mathrm{~m}, 1 \mathrm{H}), 1.07-1.04(\mathrm{~m}, 2 \mathrm{H})$, 0.69-0.66 (m, 2H). 26g: Spectral data was identical to literature compound [38]. ${ }^{1} \mathrm{H}$ NMR (300 MHz, $\left.\mathrm{CDCl}_{3}\right) \delta 7.37$ (d, $J=7.8 \mathrm{~Hz}, 2 \mathrm{H}), 6.99$ (s, 2H), 6.93 (d, $J=8.4 \mathrm{~Hz}, 2 \mathrm{H}), 2.37$ (s, $6 \mathrm{H}), 2.29$ (s, 6H).

(4-Fluorophenyl)(cyclopropyl)sulfane (1h). The general procedure was followed on $0.470 \mathrm{mmol}$ scale starting from 4-fluorobenzenethiol $(\mathbf{1 4 h})$. The residue was purified on silica gel
$(100 \% \mathrm{Hex})$ to afford $\mathbf{1 h}(65.4 \mathrm{mg}, 83 \%)$ as a colorless oil: Spectral data was identical to literature compound [38]. ${ }^{1} \mathrm{H}$ NMR (300 MHz, $\left.\mathrm{CDCl}_{3}\right) \delta$ 7.37-7.31 (m, 2H), 7.04-6.96 $(\mathrm{m}, 2 \mathrm{H}), 2.22-2.14(\mathrm{~m}, 1 \mathrm{H}), 1.07-1.01(\mathrm{~m}, 2 \mathrm{H}), 0.71-0.66(\mathrm{~m}$, $2 \mathrm{H})$.

(4-Bromophenyl)(cyclopropyl)sulfane (1i) and 1,2-bis(4bromophenyl)disulfane (26i). The general procedure was followed on $0.400 \mathrm{mmol}$ scale starting from 4-bromobenzenethiol (14i). The residue was purified on silica gel $(100 \% \mathrm{Hex})$ to afford $\mathbf{1 i}(86.9 \mathrm{mg}, 95 \%)$ and $\mathbf{2 6 i}(1.5 \mathrm{mg}, 2 \%)$ as colorless oils. 1i: Spectral data was identical to literature compound [38]. ${ }^{1} \mathrm{H}$ NMR (300 MHz, $\left.\mathrm{CDCl}_{3}\right) \delta 7.39(\mathrm{~d}, J=8.4 \mathrm{~Hz}, 2 \mathrm{H}), 7.22$ (d, $J=8.4 \mathrm{~Hz}, 2 \mathrm{H}), 2.20-2.12(\mathrm{~m}, 1 \mathrm{H}), 1.11-1.04(\mathrm{~m}, 2 \mathrm{H})$, $0.71-0.66(\mathrm{~m}, 2 \mathrm{H}) .26 \mathbf{i}$ : Spectral data was identical to literature compound [59]. ${ }^{1} \mathrm{H}$ NMR (300 MHz, $\left.\mathrm{CDCl}_{3}\right) \delta 7.43$ (d, $J=8.4$, $4 \mathrm{H}), 7.34$ (d, $J=8.4 \mathrm{~Hz}, 4 \mathrm{H})$.

(4-Chlorophenyl)(cyclopropyl)sulfane (1j) and 1,2-bis(4chlorophenyl)disulfane (26j). The general procedure was followed on $0.400 \mathrm{mmol}$ scale starting from 4-chlorobenzenethiol (14j). The residue was purified on silica gel $(100 \% \mathrm{Hex})$ to afford $\mathbf{1 j}$ (52.9 mg, 72\%) and $\mathbf{2 6 \mathbf { j }}$ (12.6 $\mathrm{mg}, 22 \%$ ) as a colorless oil and a white solid, respectively. 1j: Spectral data was identical to literature compound [38]. ${ }^{1} \mathrm{H}$ NMR $\left(300 \mathrm{MHz}, \mathrm{CDCl}_{3}\right)$ $\delta 7.30-7.22(\mathrm{~m}, 4 \mathrm{H}), 2.20-2.12(\mathrm{~m}, 1 \mathrm{H}), 1.10-1.03(\mathrm{~m}, 2 \mathrm{H})$, 0.70-0.65 (m, 2H). 26j: mp 71.0-73.0 ${ }^{\circ} \mathrm{C}$. Spectral data was identical to literature compound [60]. ${ }^{1} \mathrm{H}$ NMR (300 MHz, $\left.\mathrm{CDCl}_{3}\right) \delta 7.39(\mathrm{~d}, J=8.4 \mathrm{~Hz}, 4 \mathrm{H}), 7.27(\mathrm{~d}, J=8.7,4 \mathrm{H})$.

Cyclopropyl(4-(trifluoromethyl)phenyl)sulfane (1k). The general procedure was followed on $0.400 \mathrm{mmol}$ scale starting from 4-(trifluoromethyl)benzenethiol (14k). The residue was purified on silica gel (100\% Hex) to afford $1 \mathbf{k}(63.2 \mathrm{mg}, 72 \%)$ as a light yellow oil: Spectral data was identical to literature compound [38]. ${ }^{1} \mathrm{H}$ NMR (300 MHz, $\left.\mathrm{CDCl}_{3}\right) \delta 7.52$ (d, $J=8.4 \mathrm{~Hz}, 2 \mathrm{H}), 7.43(\mathrm{~d}, J=8.4 \mathrm{~Hz}, 2 \mathrm{H}), 2.24-2.15(\mathrm{~m}, 1 \mathrm{H})$, $1.18-1.07(\mathrm{~m}, 2 \mathrm{H}), 0.74-0.65(\mathrm{~m}, 2 \mathrm{H})$.

Cyclopropyl(4-nitrophenyl)sulfane (11). The general procedure was followed on $0.400 \mathrm{mmol}$ scale starting from 4-nitrobenzenethiol (14l). The residue was purified on silica gel (from $100 \%$ Hex to $15 \%$ EtOAc/Hex) to afford 11 (60.7 mg, $78 \%$ ) as a yellow oil: Spectral data was identical to literature compound [38]. ${ }^{1} \mathrm{H}$ NMR $\left(300 \mathrm{MHz}, \mathrm{CDCl}_{3}\right) \delta 8.13$ (d, $J=8.7 \mathrm{~Hz}, 2 \mathrm{H}), 7.44(\mathrm{~d}, J=9.0 \mathrm{~Hz}, 2 \mathrm{H}), 2.25-2.17(\mathrm{~m}, 1 \mathrm{H})$, $1.23-1.16(\mathrm{~m}, 2 \mathrm{H}), 0.77-0.72(\mathrm{~m}, 2 \mathrm{H})$.

Cyclopropyl(4-methoxyphenyl)sulfane (1m) and 1,2-bis(4methoxyphenyl)disulfane $(\mathbf{2 6 m})$. The general procedure was followed on $0.400 \mathrm{mmol}$ scale starting from 4-methoxyben- 
zenethiol (14m). The residue was purified on silica gel (from $100 \%$ Hex to $20 \%$ EtOAc/Hex) to afford 1 m $(57.4 \mathrm{mg}, 80 \%)$ and $\mathbf{2 6 m}(1.1 \mathrm{mg}, 2 \%)$ as yellow oils. $1 \mathrm{~m}$ : Spectral data was identical to literature compound [38]. ${ }^{1} \mathrm{H}$ NMR $(300 \mathrm{MHz}$, $\left.\mathrm{CDCl}_{3}\right) \delta 7.34(\mathrm{~d}, J=9.0 \mathrm{~Hz}, 2 \mathrm{H}), 6.86(\mathrm{~d}, J=8.7 \mathrm{~Hz}, 2 \mathrm{H})$ $3.80(\mathrm{~s}, 3 \mathrm{H}), 2.22-2.14(\mathrm{~m}, 1 \mathrm{H}), 1.01-0.95(\mathrm{~m}, 2 \mathrm{H}), 0.70-0.65$ $(\mathrm{m}, 2 \mathrm{H}) .26 \mathrm{~m}$ : Spectral data was identical to literature compound [61]. ${ }^{1} \mathrm{H} \mathrm{NMR}\left(300 \mathrm{MHz}, \mathrm{CDCl}_{3}\right) \delta 7.40(\mathrm{~d}, J=9.0 \mathrm{~Hz}$, $4 \mathrm{H}), 6.83(\mathrm{~d}, J=8.7 \mathrm{~Hz}, 4 \mathrm{H}), 3.80(\mathrm{~s}, 6 \mathrm{H})$.

(3-Bromophenyl)(cyclopropyl)sulfane (1n) and 1,2-bis(3bromophenyl)disulfane (26n). The general procedure was followed on $0.484 \mathrm{mmol}$ scale starting from 3-bromobenzenethiol (14n). The residue was purified on silica gel $(100 \% \mathrm{Hex})$ to afford $\mathbf{1 n}(49.9 \mathrm{mg}, 45 \%)$ and $\mathbf{2 6 n}(5.5 \mathrm{mg}, 6 \%)$ as a colorless and a yellow oil, respectively. 1n: Spectral data was identical to literature compound [38]. ${ }^{1} \mathrm{H}$ NMR $\left(300 \mathrm{MHz}, \mathrm{CDCl}_{3}\right) \delta$ 7.51-7.50 (t, $J=0.9 \mathrm{~Hz}, 1 \mathrm{H}), 7.27-7.24(\mathrm{~m}, 2 \mathrm{H}), 7.13$ (t, $J=3.9 \mathrm{~Hz}, 1 \mathrm{H}), 2.19-2.15(\mathrm{~m}, 1 \mathrm{H}), 1.12-1.09(\mathrm{~m}, 2 \mathrm{H})$, $0.72-0.69$ (m, 2H). 26n: Spectral data was identical to literature compound [38]. ${ }^{1} \mathrm{H}$ NMR $\left(300 \mathrm{MHz}, \mathrm{CDCl}_{3}\right) \delta 7.64-7.62$ (m, 2H), 7.42-7.35 (m, 4H), $7.18(\mathrm{t}, J=7.8 \mathrm{~Hz}, 2 \mathrm{H})$.

Methyl 2-(cyclopropylthio)benzoate (10) and dimethyl 2,2'disulfanediyldibenzoate (26o). The general procedure was followed on $0.400 \mathrm{mmol}$ scale starting from methyl 2-mercaptobenzoate (140). The residue was purified on silica gel (from $100 \% \mathrm{Hex}$ to $20 \% \mathrm{EtOAC} / \mathrm{Hex})$ to afford $10(36.7 \mathrm{mg}, 44 \%)$ and $260(24.1 \mathrm{mg}, 36 \%)$ as a yellow oil and a white solid, respectively. 10: Spectral data was identical to literature compound [38]. ${ }^{1} \mathrm{H}$ NMR $\left(300 \mathrm{MHz}, \mathrm{CDCl}_{3}\right) \delta 7.99(\mathrm{dd}, J=8.0$, $1.7 \mathrm{~Hz}, 1 \mathrm{H}), 7.79(\mathrm{dd}, J=8.1,1.2 \mathrm{~Hz}, 1 \mathrm{H}), 7.47$ (ddd, $J=8.7$, $7.2,1.5 \mathrm{~Hz}, 1 \mathrm{H}), 7.15$ (ddd, $J=9.0,7.2,1.2 \mathrm{~Hz}, 1 \mathrm{H}), 3.89$ (s, $3 \mathrm{H}), 2.12-2.04(\mathrm{~m}, 1 \mathrm{H}), 1.17-1.10(\mathrm{~m}, 2 \mathrm{H}), 0.74-0.69(\mathrm{~m}, 2 \mathrm{H})$. 260: $\mathrm{mp} 133.0-135.5^{\circ} \mathrm{C}$. Spectral data was identical to literature compound [62]. ${ }^{1} \mathrm{H}$ NMR $\left(300 \mathrm{MHz}, \mathrm{CDCl}_{3}\right) \delta 8.06(\mathrm{dd}$, $J=7.8,1.5 \mathrm{~Hz}, 2 \mathrm{H}), 7.76$ (dd, $J=8.3,1.1 \mathrm{~Hz}, 2 \mathrm{H}), 7.41$ (ddd, $J=8.3,7.3,1.3 \mathrm{~Hz}, 2 \mathrm{H}), 7.23(\mathrm{dd}, J=7.5,1.2,2 \mathrm{H}), 3.99$ (s, $6 \mathrm{H})$.

\section{Supporting Information}

\section{Supporting Information File 1}

Copies of NMR spectra of synthesized compounds.

[https://www.beilstein-journals.org/bjoc/content/ supplementary/1860-5397-15-113-S1.pdf]

\section{Acknowledgements}

This work was supported by Boehringer Ingelheim Pharmaceuticals, Inc. through a Scientific Advancement Grant, by a provincial Fonds de Recherche du Québec, Nature et Technologies (FRQNT) team grant and by the Centre in Green Chemistry and Catalysis (CGCC).

\section{ORCID ${ }^{\circledR}$ iDs}

Emeline Benoit - https://orcid.org/0000-0002-1692-676X

\section{References}

1. Fyfe, M. C. T.; White, J. R.; Taylor, A.; Chatfield, R.; Wargent, E.; Printz, R. L.; Sulpice, T.; McCormack, J. G.; Procter, M. J.; Reynet, C.; Widdowson, P. S.; Wong-Kai-In, P. Diabetologia 2007, 50, 1277-1287. doi:10.1007/s00125-007-0646-8

2. Mao, W.; Ning, M.; Liu, Z.; Zhu, Q.; Leng, Y.; Zhang, A. Bioorg. Med. Chem. 2012, 20, 2982-2991. doi:10.1016/j.bmc.2012.03.008

3. ClinicalTrialsgov identifier: NCT01247363: A Study of LY2608204 in Patients with Type 2 Diabetes.

4. Deshpande, A. M.; Bhuniya, D.; De, S.; Dave, B.; Vyavahare, V. P.; Kurhade, S. H.; Kandalkar, S. R.; Naik, K. P.; Kobal, B. S.; Kaduskar, R. D.; Basu, S.; Jain, V.; Patil, P.; Chaturvedi Joshi, S.; Bhat, G.; Raje, A. A.; Reddy, S.; Gundu, J.; Madgula, V.; Tambe, S.; Shitole, P.; Umrani, D.; Chugh, A.; Palle, V. P.; Mookhtiar, K. A. Eur. J. Med. Chem. 2017, 133, 268-286. doi:10.1016/j.ejmech.2017.03.042

5. ClinicalTrials.gov identifier: NCT01247363: Phase 1 study of LY2608204 in patients with Type 2 Diabetes Melitus.

6. Lücking, U.; Jautelat, R.; Krüger, M.; Brumby, T.; Lienau, P.; Schäfer, M.; Briem, H.; Schulze, J.; Hillisch, A.; Reichel, A.; Wengner, A. M.; Siemeister, G. ChemMedChem 2013, 8, 1067-1085. doi:10.1002/cmdc.201300096

7. Nishimura, N.; Norman, M. H.; Liu, L.; Yang, K. C.; Ashton, K. S.; Bartberger, M. D.; Chmait, S.; Chen, J.; Cupples, R.; Fotsch, C.; Helmering, J.; Jordan, S. R.; Kunz, R. K.; Pennington, L. D.; Poon, S. F.; Siegmund, A.; Sivits, G.; Lloyd, D. J.; Hale, C.; Jean, D. J. St. J. Med. Chem. 2014, 57, 3094-3116. doi:10.1021/jm5000497

8. Lohier, J.-F.; Glachet, T.; Marzag, H.; Gaumont, A.-C.; Reboul, V. Chem. Commun. 2017, 53, 2064-2067. doi:10.1039/c6cc09940h

9. Reck, M.; Horn, L.; Novello, S.; Barlesi, F.; Albert, I.; Juhász, E.; Kowalski, D.; Robinet, G.; Cadranel, J.; Bidoli, P.; Chung, J.; Fritsch, A.; Drews, U.; Wagner, A.; Govindan, R. J. Thorac. Oncol. 2019, 14, 701-711. doi:10.1016/j.jtho.2019.01.010

10. Bumgardner, C. L.; Lever, J. R.; Purrington, S. T. Tetrahedron Lett. 1982, 23, 2379-2382. doi:10.1016/s0040-4039(00)87347-5

11. Trost, B. M.; Vladuchick, W. C. Synthesis 1978, 821. doi:10.1055/s-1978-24897

12. Kwon, T. W.; Smith, M. B. Synth. Commun. 1992, 22, 2273-2285. doi:10.1080/00397919208019081

13. Trost, B. M.; Keeley, D. E.; Arndt, H. C.; Bogdanowicz, M. J. J. Am. Chem. Soc. 1977, 99, 3088-3100. doi:10.1021/ja00451a040

14. Horiguchi, Y.; Suehiro, I.; Sasaki, A.; Kuwajima, I. Tetrahedron Lett. 1993, 34, 6077-6080. doi:10.1016/s0040-4039(00)61732-x

15. Grover, H. K.; Emmett, M. R.; Kerr, M. A. Org. Biomol. Chem. 2015, 13, 655-671. doi:10.1039/c4ob02117g

16. Bernard, A. M.; Frongia, A.; Secci, F.; Delogu, G.; Ollivier, J.; Piras, P. P.; Salaün, J. Tetrahedron 2003, 59, 9433-9440. doi:10.1016/j.tet.2003.09.074 
17. Bernard, A. M.; Frongia, A.; Secci, F.; Piras, P. P. Chem. Commun. 2005, 3853-3855. doi:10.1039/b505707h

18. Masson, E.; Leroux, F. Helv. Chim. Acta 2005, 88, 1375-1386. doi:10.1002/hlca.200590110

19. Banning, J. E.; Prosser, A. R.; Alnasleh, B. K.; Smarker, J.; Rubina, M.; Rubin, M. J. Org. Chem. 2011, 76, 3968-3986. doi:10.1021/jo200368a

20. Lin, H.-C.; Tsai, R.-T.; Wu, H.-P.; Lee, H.-Y.; Lee, G.-A. Tetrahedron 2016, 72, 184-191. doi:10.1016/j.tet.2015.11.024

21. Kozhushkov, S. I.; Brandl, M.; de Meijere, A. Eur. J. Org. Chem. 1998, 1535-1542. doi:10.1002/(sici)1099-0690(199808)1998:8<1535::aid-ejoc1535>3.3.c o;2-g

22. Volta, L.; Stirling, C. J. M. Phosphorus, Sulfur Silicon Relat. Elem. 2009, 184, 1508-1522. doi:10.1080/10426500902947856

23. Tanaka, K.; Uneme, H.; Matsui, S.; Kaji, A. Bull. Chem. Soc. Jpn. 1982 55, 2965-2972. doi:10.1246/bcsj.55.2965

24. Gagnon, A.; Dansereau, J.; Le Roch, A. Synthesis 2017, 49, 1707-1745. doi:10.1055/s-0036-1589482

25. Gagnon, A.; Benoit, E.; Le Roch, A. Sci. Synth., Knowl. Updates 2018, 4, 1.

26. Gagnon, A.; Albert, V.; Duplessis, M. Synlett 2010, 2936-2940. doi:10.1055/s-0030-1259023

27. Petiot, P.; Gagnon, A. Eur. J. Org. Chem. 2013, 5282-5289. doi:10.1002/ejoc.201300850

28. Petiot, P.; Gagnon, A. Heterocycles 2014, 88, 1615-1624. doi:10.3987/com-13-s(s) 114

29. Dansereau, J.; Gautreau, S.; Gagnon, A. ChemistrySelect 2017, 2 , 2593-2599. doi:10.1002/slct.201700438

30. Petiot, P.; Dansereau, J.; Gagnon, A. RSC Adv. 2014, 4, 22255-22259. doi:10.1039/c4ra02467b

31. Crifar, C.; Petiot, P.; Ahmad, T.; Gagnon, A. Chem. - Eur. J. 2014, 20 , 2755-2760. doi:10.1002/chem.201303684

32. Petiot, P.; Dansereau, J.; Hébert, M.; Khene, I.; Ahmad, T.; Samaali, S.; Leroy, M.; Pinsonneault, F.; Legault, C. Y.; Gagnon, A. Org. Biomol. Chem. 2015, 13, 1322-1327. doi:10.1039/c4ob02497d

33. Ahmad, T.; Dansereau, J.; Hébert, M.; Grand-Maître, C.; Larivée, A.; Siddiqui, A.; Gagnon, A. Tetrahedron Lett. 2016, 57, 4284-4287. doi:10.1016/j.tetlet.2016.08.021

34. Hébert, M.; Petiot, P.; Benoit, E.; Dansereau, J.; Ahmad, T.; Le Roch, A.; Ottenwaelder, X.; Gagnon, A. J. Org. Chem. 2016, 81, 5401-5416. doi:10.1021/acs.joc.6b00767

35. Gagnon, A.; St-Onge, M.; Little, K.; Duplessis, M.; Barabé, F. J. Am. Chem. Soc. 2007, 129, 44-45. doi:10.1021/ja0676758

36. Gagnon, A.; Duplessis, M.; Alsabeh, P.; Barabé, F. J. Org. Chem. 2008, 73, 3604-3607. doi:10.1021/jo702377h

37. Benoit, E.; Dansereau, J.; Gagnon, A. Synlett 2017, 28, 2833-2838. doi:10.1055/s-0036-1590832

38. Benoit, E.; Bueno, B.; Choinière, C.; Gagnon, A. J. Organomet. Chem. 2019, 893, 72-77. doi:10.1016/j.jorganchem.2019.04.032

39. Bénard, S.; Neuville, L.; Zhu, J. J. Org. Chem. 2008, 73, 6441-6444. doi:10.1021/j0801033y

40. Bénard, S.; Neuville, L.; Zhu, J. Chem. Commun. 2010, 46, 3393-3395. doi:10.1039/b925499d

41. Tsuritani, T.; Strotman, N. A.; Yamamoto, Y.; Kawasaki, M.; Yasuda, N.; Mase, T. Org. Lett. 2008, 10, 1653-1655. doi:10.1021/ol800376f

42. Racine, E.; Monnier, F.; Vors, J.-P.; Taillefer, M. Chem. Commun. 2013, 49, 7412-7414. doi:10.1039/c3cc42575d

43. Haneda, S.; Sudo, K.; Hayashi, M. Heterocycles 2012, 84, 569-575. doi:10.3987/com-11-s(p)20
44. Tambe, Y. B.; Sharma, S.; Pathak, A.; Reddy, L. K. Synth. Commun. 2012, 42, 1341-1348. doi:10.1080/00397911.2010.539758

45. Chan, D. M. T.; Monaco, K. L.; Wang, R.-P.; Winters, M. P. Tetrahedron Lett. 1998, 39, 2933-2936. doi:10.1016/s0040-4039(98)00503-6

46. Evans, D. A.; Katz, J. L.; West, T. R. Tetrahedron Lett. 1998, 39 , 2937-2940. doi:10.1016/s0040-4039(98)00502-4

47. Lam, P. Y. S.; Clark, C. G.; Saubern, S.; Adams, J.; Winters, M. P.; Chan, D. M. T.; Combs, A. Tetrahedron Lett. 1998, 39, $2941-2944$. doi:10.1016/s0040-4039(98)00504-8

48. Evano, G.; Blanchard, N., Eds. Copper-Mediated Cross-Coupling Reactions; John Wiley and Sons Ltd.: Hoboken, NJ, U.S.A., 2013. doi:10.1002/9781118690659

49. Evano, G.; Blanchard, N.; Toumi, M. Chem. Rev. 2008, 108, 3054-3131. doi:10.1021/cr8002505

50. Monnier, F.; Taillefer, M. Angew. Chem., Int. Ed. 2009, 48, 6954-6971. doi:10.1002/anie.200804497

51. Sambiagio, C.; Marsden, S. P.; Blacker, A. J.; McGowan, P. C. Chem. Soc. Rev. 2014, 43, 3525-3550. doi:10.1039/c3cs60289c

52. Derosa, J.; O’Duill, M. L.; Holcomb, M.; Boulous, M. N.; Patman, R. L.; Wang, F.; Tran-Dubé, M.; McAlpine, I.; Engle, K. M. J. Org. Chem. 2018, 83, 3417-3425. doi:10.1021/acs.joc.7b03100

53. Xu, H.-J.; Zhao, Y.-Q.; Feng, T.; Feng, Y.-S. J. Org. Chem. 2012, 77, 2878-2884. doi:10.1021/jo300100x

54. Herradura, P. S.; Pendola, K. A.; Guy, R. K. Org. Lett. 2000, 2, 2019-2022. doi:10.1021/ol005832g

55. Hayashi, M.; Okunaga, K.-i.; Nishida, S.; Kawamura, K.; Eda, K. Tetrahedron Lett. 2010, 51, 6734-6736. doi:10.1016/j.tetlet.2010.10.070

56. Figuly, G. D.; Martin, J. C. J. Org. Chem. 1980, 45, 3728-3729. doi:10.1021/jo01306a041

57. Taniguchi, N. Synlett 2005, 1687-1690. doi:10.1055/s-2005-871545

58. Spurg, A.; Schnakenburg, G.; Waldvogel, S. R. Chem. - Eur. J. 2009, 15, 13313-13317. doi:10.1002/chem.200902466

59. Loghmani-Khouzani, H.; Poorheravi, M. R.; Sadeghi, M. M. M.; Caggiano, L.; Jackson, R. F. W. Tetrahedron 2008, 64, 7419-7425. doi:10.1016/j.tet.2008.05.034

60. Shojaei, A.; Rezvani, M.; Heravi, M. J. Serb. Chem. Soc. 2011, 76, 955-963.

61. Oba, M.; Tanaka, K.; Nishiyama, K.; Ando, W. J. Org. Chem. 2011, 76, 4173-4177. doi:10.1021/jo200496r

62. Misra, A. K.; Agnihotri, G. Synth. Commun. 2004, 34, 1079-1085. doi:10.1081/scc-120028640 


\section{License and Terms}

This is an Open Access article under the terms of the Creative Commons Attribution License

(http://creativecommons.org/licenses/by/4.0). Please note that the reuse, redistribution and reproduction in particular requires that the authors and source are credited.

The license is subject to the Beilstein Journal of Organic Chemistry terms and conditions:

(https://www.beilstein-journals.org/bjoc)

The definitive version of this article is the electronic one which can be found at:

doi:10.3762/bjoc. 15.113 